убежища. Среди них трудности с обращением в соответствующие учреждения и назначением времени для обязательного собеседования. Иногда требуется несколько месяцев, в течение которых сирийцы находятся на территории России нелегально. В связи с этим они не могут пользоваться всеми предусмотренными законом правами, выполнять свои обязанности, пока им угрожает высылка из страны [5, с. 4].

В последнее время на родину возвращается все больше беженцев, в том числе из-за трудностей с получением гражданства [6, с.113]. Например, Верховный суд не принял к рассмотрению жалобу гражданина Сирии об отказе в представлении убежища. Суд установил, что в их родной стране нет военного противостояния, а проводится контртеррористическая операция, и поэтому гражданам не следует опасаться бесчеловечного обращения. Хотя на сегодняшний день ситуация немного изменилась, существуют большие проблемы в данной области после прихода новой власти, что введет к напряженным отношениям во всем мире.

Таким образом, проблема беженцев остается очень актуальной и сегодня. Так все государства, принимающие беженцев, должны очень четко понимать, что у них есть обязательства не только принимать мигрантов, но и обеспечивать защиту их законных интересов и прав, соблюдение беженцами обязательств, предусмотренных законом. В то же время необходимо ужесточить систему пропусков, чтобы не допустить въезда боевиков на территорию Российской Федерации под видом беженцев. Не допускать на территорию страны лиц, склонных к совершению актов насилия, чтобы не нарушались права граждан Российской Федерации. В то же время мировое сообщество должно определить наиболее эффективные способы предотвращения всех новых притоков беженцев в разные государства. Эти способы включают изучение первопричин этих явлений и принятие мер по улучшению ситуации. Поэтому власти стран, из которых прибывают беженцы, должны обеспечивать безопасность своих граждан и защищать их права в случае такой необходимости, предотвратить возникновение вооруженного конфликта и других чрезвычайных ситуаций на территории государства. Как показал опыт последних лет, международное сообщество и отдельные государства должны постоянно проводить работу, необходимую для решения многих проблем беженцев и быть всегда готовыми действовать в чрезвычайных ситуациях.

$$
\text { *** }
$$

1. Игнатенко Г. В., Тиунов О. И, Учебник / Отв. ред. Игнатенко Г. В., Тиунов О. И. - 6-е изд., перераб. и доп. М.: Юр.Норма, НИЦ ИН-ФРА-М, 2017. - 752 с.

2. Федеральный закон "О гражданстве Российской Федерации" от 31.05.2002 N 62-Ф3 (последняя редакция)// [Электронная версия] http://www.consultant.ru/document/cons_doc_LAW_36927/ .

3. Конвенция о статусе беженцев (Женева, 28 июля 1951 г.) // [Электронная версия] https://base.garant.ru/2540374/ .

4. Федеральный закон от 19.02.1993 N 4528-1 (ред. от 01.07.2021) "О беженцах"// [Электронная версия] http://www.consultant.ru/document/cons_doc_LAW_4340/.

5. Карасёва Л.В. Значение норм международного частного права в регулировании трудовых отношений мигрантов из стран СНГ в Российской Федерации. автореферат диссертации на соискание ученой степени кандидата юридических наук / Российский государственный социальный институт. Москва, 2007. С. 8.

6. Значение норм международного частного права в регулировании трудовых отношений мигрантов из стран СНГ в Российской Федерации / Кудрявцева Л.В. - Краснодар: Парабеллум, 2011. - 240 с.

\title{
Пузиков С.А. \\ О некоторых особенностях заключения договора догазификации в 2021 году
}

Волгоградский государственньй университет (Россия, Волгоград)

doi: 10.18411/trnio-01-2022-193

Аннотация

В статье кратко рассмотрены отдельные проблемные вопросы, связанные с заключением договора догазификации в 2021 году в виду реформирования рынка.

Ключевые слова: догазификация, газоснабжение, специализированные организации. 


\section{Abstract}

The article briefly examines individual problems, issues related to the conclusion of a pregasification agreement in 2021 in view of market reform.

Keywords: pre-gasification, gas supply, specialized organizations.

Необходимо особо отметить, что вступившие в силу с 18.10.2021г. Правила подключения (также наряду с этим в Правилах применяется термин, имеющий аналогичное значение - технологическое присоединение) оборудования, использующего газ в качестве топлива и объектов капитального строительства к сетям газораспределения, были утверждены Постановлением Правительства РФ от 13.09.2021 N 1547 (далее также Правила подключения 2021 года) и существенным образом, изменили действовавший ранее порядок заключения договоров подключения.

Термин «догазификация» (договор догазификации) впервые в отечественном законодательстве был введен в гражданский оборот именно Правилами подключения 2021 года.

Главное отличие указанного договора от ранее действовавших договоров подключения или иных подрядных (договоров возмездного оказания услуг) договоров исполнитель (он же подрядчик, он же особый субъект, обладающий установленными законодательством признаками - территориальная газораспределительная организация) обязан подключить оборудование заявителя (физическое лицо), использующее газ в качестве топлива (определяющее значение имеют цели использования газа - удовлетворение личных, семейных, домашних и иных нужд, не связанных с извлечением дохода (каким либо предпринимательством), при этом строительство газопроводов непосредственно до принадлежащего такому физическому лицу участка, производится исполнителем без получения оплаты от заявителя.

Единственное условие - это наличие в населённом пункте, в котором находится заявитель, уже построенных ранее сетей газораспределения.

Исполнитель обязан (в случае если заявитель обратится с соответствующим заявлением) также обеспечить строительство сетей газопотребления внутри земельного участка заявителя, поставить и подключить необходимое газоиспользующие оборудование и приборы учёта.

При этом, предусматривается государственное регулирование всех оказываемых в рамках газификации услуг и работ (за исключением стоимости самого оборудования). В договоре догазификации также появляется третья сторона - единый (а при наличии, региональный) оператор газификации (далее также ЕОГ, согласно 2 ФЗ о газоснабжении от 31.03.1999г. № 69-Ф3 в качестве ЕОГ может быть исключительно организация, являющаяся собственником единой системы газоснабжения РФ, обеспечивает подключение указанной категории заявителей [1].

Необходимо отметить, что бесплатное для заявителей подведение газораспределительных сетей до границ земельного участка предусмотрено нормативным актом в российском законодательстве впервые. Очевидно, что введение указанной нормы имеет прежде всего социальное значение. Впервые правила подключения имеют срок своего действия, а именно 6 лет (т.е. до 18.10.2027г.).

Таким образом, предполагается что до указанного сроку вся возможная газификации в Российской Федерации будет максимально завершена, а по окончании данного срока будут введены иные Правила подключения.

Правила подключения 2021 года чётко прописывают процедуру подключения: заявитель направляет единому (региональному) оператору газификации заявку по типовой форме, утверждённой Правилами, заключается договор подключения по типовой же форме, заявитель и исполнитель выполняют условия договора, составляется акт о готовности сетей и оборудования по типовой форме и осуществляется фактическое присоединение объекта 
капительного строительства с составлением акта о подключении, который также должен быть составлен по типовой форме.

Важной особенностью является то, что заявка о подключении может быть подана не только в офисе, но и через личный кабинет, через МФЦ (многофункциональная организация, предоставляющая комплекс различных услуг, как государственных, так и муниципальных), через Единый или региональный портал таких услуг (особая федеральная информационная система). Следует приветствовать продвижение цифровизации в такой важной сфере как газификация. В целом цифровые права являются новым объектом гражданских прав. По мнению ряда авторов, существование цифрового права в рамках информационных систем не позволяет в полной мере учесть их специфический характер [2]. Однако использование цифровых информационных систем при проведении газификации является оправданным и удобным для всех участников данного процесса.

В рассматриваемом случае, физическое лицо получает доступ к своему личному кабинету, используя Единую систему аутентификации, позволяющей произвести идентификацию, которая в свою очередь обеспечит технолгическое взаимодействие с необходимыми системами госуслуг в электронной форме. Предусматривается, что физические лица смогут для этого использовать простую электронную подпись.

В Правилах прописывает обязанность для организаций, оказывающих услуги по догазификации обеспечить в своих офисах возможность доступа граждан к личному кабинету (без взимания платы) и предоставлять им сведения о том, какие документы размещаются в личном кабинете заявителя и подлежат оформлению в процессе подключения. В целях доступности информирования потенциальных заявителей предусмотрено что перечень всех газораспределительных организаций, а также населённых пунктов, в которых имеются газораспределительные сети, размещаются на официальных ресурсах (сайтах) ЕОГ, газораспределительных организаций с указанием всей необходимой информации, позволяющей принять решение о газификации.

ЕОГ и исполнитель обязаны обеспечить принятие в электронном виде заявок о подключении и прилагаемых документов от заявителей

Правила подключения 2021 года предъявляют минимально необходимый исчерпывающий набор требований к заявке. В заявке необходимо указать помимо своих реквизитов, адресов и контактов, наименование и местонахождения объекта, характер потребления газа (коммерческий или нет), сроки проектирования и строительства объекта, желаемое разделение расхода газа по точкам (если их несколько, например, баня, дом, теплица), номер и дата технических условий, реквизиты проекта межевания территории или схемы земельного участка на кадастровом плане. К заявке должны быть приобщены следующие документы: ситуационный план (условная схема), масштабированная (1:500) топокарта участка (только для юридических лиц), документ, предоставляющий законные права на объект строительства или земельный участок, доверенность (в случае если действует представитель), расчет максимального часового расхода газа (не прилагается, если планируемый максимальный часовой расход газа не более 7 куб. метров, т.е. не требуется для большинства жилых домов), документы, предусмотренные пунктом 106 Правил, документ о проектировании и межевании участка (в случае если подаётся заявка о комплексном развитии территории), правоустанавливающий документ на домовладении и земельный участок, ИННН и СНИЛС (в случае подачи заявки на догазификацию). При этом исполнитель должен (в случае поступления обращения) безвозмездно предоставить информацию о желаемом максимальном часовом расходе газа для если он не превышает 7 куб.м. [3].

Единственным основанием для отказа от заключения договора о подключении является отсутствие технической возможности подключения (отсутствует пропускная способность, объекта нет ни в одной из программ). В этом случае, заявитель может обратиться в уполномоченный государственный орган с предложением о включении объекта в программу газификации, либо обратиться к исполнителю с предложением о заключении 
договора о подключении по индивидуальному проекту. Юридические лица, владеющие сетями, но не оказывающие услуг, связанных с подачей газа, не вправе препятствовать подключению (технологическому присоединению) к принадлежащим им сетям газораспределения и (или) газопотребления при наличии пропускной способности таких сетей.

Датой заключения договора подключения считается дата поступления исполнителю подписанного со стороны заявителя договора в письменной форме, а случае заключения договора через личный кабинет то момент подписания цифровой подписью.

Существенными условиями договора подключения помимо мероприятий, выполняемых сторонами являются: сроки подключения, разграничение имущественной ответственности, порядок и размер внесения платы за подключение (искл. - догазификация), стоимость проекта и экспертизы (для индивидуальных проектов), ответственность сторон и неустойка за просрочку исполнения обязательств, технические условия, право заявителя на односторонний отказ от исполнения договора, обязанность для исполнителя исполнить договор в т.ч. когда необходимо строительство на земельных участках третьих лиц включая обращение в адрес уполномоченных государственных органов за установлением публичного сервитута, мониторинг исполнения технических условий.

Сроки подключения устанавливаются Правилами в зависимости от категории заявителя: не более 135 дней для заявителей 1 категории (часовой расход не более 42 куб.м., а расстояние от участка до газораспределительной сети не более 200м); 1,5 года для заявителей 2 категории ( не более 500м для территории вне населённых пунктов и не более 300 м в населённых пунктах); 2 года для заявителей 3 категории (соответственно протяжённость превышает указанные показатели либо система газораспределения затрагивает сразу два или более муниципальных образований). Правилами также в конкретных календарных показателях установлены основания и сроки продления мероприятий по подключению [3].

Детальная регламентация Правилами подключения всех процедур, возникающих в процессе выполнения мероприятий по технологическому присоединению направлена прежде всего на защиту интересов заявителей, вносит временную определённость и содействует вовлечению максимально большого количества заявителей в процессы газификации.

$$
* * *
$$

1. Федеральный закон от 31.03.1999 N 69-Ф3 «О газоснабжении в Российской Федерации» // СПС КонсультантПлюс;

2. Казаченок О.П. Цифровые права в современном гражданском обороте: тенденции и перспективы развития// Хозяйство и право. 2019, №11, ст.39-44;

3. Постановление Правительства РФ от 13.09.2021 N 1547 «Об утверждении Правил подключения (технологического присоединения) газоиспользующего оборудования и объектов капитального строительства к сетям газораспределения» // СПС КонсультантПлюс.

\title{
Пузиков С.А. \\ О некоторых особенностях развития инноваций в условиях конкуренции и антимонопольного регулирования
}

Волгоградский государственньй университет (Россия, Волгоград)

doi: 10.18411/trnio-01-2022-194

Научньй руководитель: Копьев А.В.

\author{
Аннотация \\ В статье кратко рассмотрены отдельные проблемные вопросы, связанные с развитием \\ инноваций в условиях конкуренции.
}

Ключевые слова: инновация, антимонопольная служба, конкуренция. 